\title{
Glocal Spirituality
}

\section{For a brave new world}

$\mathrm{O}$

ne of my colleagues spent a long time among the Maasai in Kenya, learning about their religion, language, and culture. When on an excursion he felt the need to respond to the call of nature. He excused himself and walked to some bushes nearby. Upon his return, two young Maasai men exchanged meaningful looks, and suddenly one of them ran to the place where the Swedish scholar had relieved himself. When he came back he smiled and said to his friend: 'Yes, it has the same smell as ours!'

The empirical research of the young Maasai could be regarded as a search for commonalities. As far as the body and bodily functions are concerned it is, of course, not difficult to find aspects of life that we share with others. When we are in the sauna, there is no difference between nobility and the commoner, between the privileged and unprivileged. If we move from somatic viewpoints to the psychological level, then there still are common denominators between people of different cultures. We all have cognitive capacities, and we all share different types of feelings. On the cultural level, however, there are differences. We can all laugh, but we do not laugh at the same kind of jokes.

In top-level politics we sometimes notice that politicians leave their prestigious positions and associate as ordinary human beings. If I am well informed, this is what happened at Camp David, USA, when Israeli Menachem Begin met his counterpart, the Egyptian Anwar Sadat, under the supervision of President Jimmy Carter. When negotiations were kind of sluggish, they showed each others pictures of their grandchildren. After that, there was agreement.

Perhaps this is the kind of social activity that is needed in a brave new world. If top-level politicians, and their low-level counterparts, as well as other persons in leading positions, every now and then can step down from their ivory tower and privileged positions and look at pictures from their family albums, then that would give me hope. And if they forgot their pictures, they could cook dinner together, or do some gardening. Such action would remind them of their humanity. Perhaps they would wake up and discover that life is worth living-and preserving; that nature is worth respecting and 
caring for; and that our universe gives us a sense of wonder and surprise. Despite all technological progress, life is still a mystery. We do not even understand our own mind.

The mysteriousness of the human predicament ought to create a sense of humility. The fragility of the human predicament ought to create a feeling that we all belong to the very same humanity. Life in the world has always been unpredictable, but it has never been as unforeseen or incalculable as it is in our time. People are struck by natural disasters, such as tsunamis, earthquakes, and cyclones.

What has all this to do with spirituality? In my opinion, spirituality, as it will be presented in a little while, can serve as an antidote to an all too disrespectful attitude towards our fellow human beings, towards life in general.

If the world is 'a tale, told by an idiot, full of sound and fury, signifying nothing', then there will be egoism instead of altruism, selfishness instead of unselfish action in the service of mankind. If the Scottish king Macbeth, in the version of Shakespeare, is right, then bad turns to worse. World leaders and people in powerful positions will continue providing privileges to the loyal and suppressive action to the unprivileged and 'disloyal'. Feudal society is alive and well, although in different forms.

Spirituality can be an antidote to this selfish and destructive attitude. Spirituality might unite a greater part of the world in the battle for survival. Our world, Gaia, is threatened, as we all know. Apart from the usual disasters as seemingly never-ending wars and conflicts we now also have to confront global threats such as climate changes, global pollution, and food distribution problems. In such a world everything has to be done in order to promote the fundamental idea that we only have one planet and one humanity.

Spirituality addresses such issues. Spirituality, in the words of Linda Woodhead, comprises two poles, one personal and one cosmic. On the one hand, man feels the urge to develop his or her own potential; on the other hand, no man is an island, as the poet (John Donne) says, we are all part of the continent. This holistic view takes egalitarianism for granted. It also provides a new interpretation of the archaic idea of living on Mother Earth, who is in need of our careful attention.

The purpose of this paper is to show that people who express the view that they are 'spiritual, not religious', people belonging to what can be called the new spirituality, despite their aversion to institutionalized religion nevertheless exhibit elements in their belief-systems that are closely related to the great mystical traditions in world religion. These common denominators are, I think, a good ground for dialogue. When theologians from especially the 
theistic traditions more often than not search for differences, mystics and representatives for the new spirituality are more inclined to find commonalities. At a time when elements of traditional Christianity such as the belief in a transcendent God show signs of being in decline, there seems to be an increasing interest in the predominant mystical and panentheistic view of God, stating that God is both immanent and transcendent.

\section{The new spirituality}

It is perhaps unnecessary to mention that one has to make a choice in the extensive research that has been reported in the field of spirituality during the last decade. A few years ago, Paul Heelas and Linda Woodhead suggested that the spiritual revolution in our time can be described as a 'massive subjective turn' from what they call 'life-as religion', largely coinciding with traditional churches, to 'subjective-life spirituality', emphasizing man's inner resources and its cultivation and sacralisation. The former is declining, while the latter appears to be growing (Heelas \& Woodhead 2005: 2 ff.). In his latest book, Heelas confesses that he is deeply committed to the beneficial efficacy of inclusivistic (albeit tension-laden) humanistic values - the same values that are sacralised by so many New Age spiritualities of life.' I do welcome this confession, with which I sympathise, and I also share his standpoint that this growing form 'of holistic, mind-body spirituality activities' might prove to be 'valuable, perhaps invaluable, ultimate resources' (Heelas 2008: 10, $14 \mathrm{f}$.). Spirituality as a resource for increasing peace and understanding is precisely my message or errand.

The expression 'new spirituality' has been borrowed from a book by James A. Herrick (2003), Professor of Communication. In his study of the roots of contemporary spirituality in the history of Western religious thought he points to a dramatic change in the American religious landscape during the last fifty years. Quoting sociologist Robert Wuthnow, Herrick talks about a 'transformation of American spirituality' (p. 19), and he then mentions a number of well-known examples of popular public spirituality. Carlos Castaneda's widely disseminated books about Don Juan from the late sixties and seventies are one example. Shirley MacLaine's bestselling publications about her spiritual journey from the eighties are another one. The list can easily be extended. Marilyn Ferguson's book The Aquarian Conspiracy (1980) found numerous readers, as did The Celestine Prophecy (1993) and other books of James Redfield. The increased interest in the relation between science and 
spirituality can also be added to the list. Starting with Fritjof Capra's The Tao of Physics (1975) and his 1982 bestseller The Turning Point, we can add a long list of similar texts, including Gary Zukav's The Dancing Wu Li Masters (1984) (see Herrick 2003: 19 ff.). During the last decade we can also notice an interest in the relation between Buddhism and Science. An extensive anthology with this title was published in 2003 and recently the Templeton Foundation published a book on Tibetan Buddhism and modern physics, written by Vic Mansfield, Professor of Physics and Astronomy (2008).

We are all familiar with the books mentioned and an additional number of them. There is no need for an exposé of this sort of popular literary genre. Instead, let's go into the question of how Herrick presents the characteristics of this new spirituality and its relation to the 'revealed word' of old time Christianity. This word is, of course, still valid for numerous Christians in our time. The 'revealed word', as Herrick calls it, consists of elements such as (1) the supernatural authority of the Judeo-Christian scriptures, delivered to humanity through the medium of for example prophetic utterance and the teachings of Jesus of Nazareth; (2) a personal God, who (3) is creator of the universe, and (4) acts and intervenes in history. A fifth element is (5) the notion of the fall of humankind and its catastrophic consequences, (6) the redemptive sacrifice of Jesus Christ and, finally, (7) the belief in a final judgment of the human race (Herrick 2003: $32 \mathrm{f}$.). ${ }^{1}$

The contents of this new spirituality show a 'new religious synthesis', as Herrick calls it, comprising (1) a conviction that 'history is not spiritually important'; and (2) sacred texts are understood as largely symbolic, allegorical, or mythic. Other characteristics are (3) the dominance of reason or consciousness as tools in order to gain spiritual insights; (4) the spiritualization of science; (5) the animation of nature, infused as it is with a life force; (6) the existence of hidden spiritual knowledge, accessible to gifted persons and, in principle, to each and every one of us; and finally (7) religious pluralism as rooted in mystical experience (Herrick 2003: 33 f.). This last characteristic is precisely what I will go in to in a little while.

In his final considerations, Herrick, in sharp contrast to Heelas, leaves us in no doubt that he dislikes the new religious synthesis, as expressed in the new spirituality. In its so-called triumph over traditional religion, 'it dispenses with a transcendent and personal deity, irrevocable forgiveness of sin, 
triumph over death, egalitarian spiritual community and the simple joy of accepting our unchangeable status as infinitely valuable but fallen creatures of a living and holy God.' In his final analysis, Herrick turns out to be a defender of the revealed word.

Heelas finds another sympathizer in the American philosopher of religion, Robert K. C. Forman, whose work mirrors an interest not only in traditional spirituality in world religion (see e.g. Forman 1990, 1998) but also in what he and his associates call 'grassroots spirituality' (Forman 2004). Their study is based on interviews with approximately 92 persons occupying 'key-positions' in different spiritual movements. The informants had different religious backgrounds-for example Christian, Jewish, Buddhist, and Sufi. The analysis of the interviews gave rise to a descriptive definitions of spirituality, comprising

- a vaguely panentheistic ultimate that

- is indwelling, sometimes bodily, as the deepest self and

- accessed through not-strictly-rational means of

- self transformation and group processes

- that becomes the holistic organization for all life (Forman 2004: 51).

Concerning his informants' view of God, Forman notices that not one single person referred to the Western view of a transcendent father or mother (p. 57). Panentheistic descriptions of God are the opposite of the 'hierarchical king model'. Since we all are part of the same One, the same basic ground, this view of God is compatible with 'our democratic and egalitarian mindset' (p. 59). When Forman describes the second aspect of his definition, God as indwelling, as the deepest self, he refers to the atman or purusha of Hinduism, the scintilla animae, the little spark, of Meister Eckhart, ${ }^{3}$ or the Shekhinah of Jewish mysticism (p. 60). This dimension can be accessed through not-strictly-rational processes, meaning that they are part of a never-ending process of self-transformation, a process including and reaching beyond rationality. Many informants said that this view functions as a good ground for dialogue with representatives of other spiritual traditions. Adherents of grassroots spirituality, Forman asserts, are all 'functional henotheists', that is persons who stick to their own interpretation of the Absolute, but are open to other interpretations (p. 91, 105). 
This final remark reminds me of similar statements, presented by academics. In The Case for Religion (2004), the British scholar Keith Ward connects to the pluralistic hypothesis of his fellow-countryman, the philosopher of religion John Hick. It says that all religious traditions contain partial truths, that the divine world defies all description. There are so many ways of relating to the transcendent world. No one tradition has the right to claim that they possess the only truth. The world of physics offers a similar basic view. No physicist would say that he or she has access to a complete picture of the universe; but they would agree that there are numerous partial truths. This is what Ward regards as a shift from religion to spirituality, a shift from exclusive dogma to inclusive religiosity, grounded in personal experience. It is a tribute to multiplicity, while simultaneously relying on the conviction that spiritual truth, fundamentally, is unitary (Ward 2004: $226 \mathrm{ff}$.).

The American islamologist Charles Kimball expresses a similar view. Let me just quote a significant statement in his book When Religion Becomes Evil (2002). Here is the quote:

I am convinced that it is possible to be a person of faith with integrity - a Christian, a Jew, a Muslim, a Buddhist - and at the same time recognize that one's own experience of God does not exhaust all the possibilities. A constructive outlook of religious pluralism can take us beyond simple diversity and embracing it as a source of strength. Rather than being necessarily divisive, religious traditions can provide models for tolerance. (Kimball 2002: 8 f.)

The reference to Keith Ward and the quote from Charles Kimball naturally lead us into another issue, pertaining to questions of globalization. The Swedish scholar Liselotte Frisk (2009) has written an interesting article about the importance of globalization for religious change. Referring to a number of contemporary scholars of spirituality, including Paul Heelas, Linda Woodhead, Ursula King, and Eileen Barker, she discovered six interlinked characteristics pertaining to contemporary religious change, characteristics touched upon by the authors mentioned. Although Frisk is reluctant to talk about 'a major cultural shiff'-far too strong expression-she nevertheless thinks that there certainly is change, important change. I will now present these characteristics, which then will be related to the different descriptions of the new spirituality, as presented above.

The first characteristic is labelled from particular to eclectic. Rather than relying on one religion, one source, contemporary spirituality seems to use the 
easily accessed world religions as different resources, creating a worldview or a religiosity that appears to be unique to each person. As a result of globalization, there is increasing communication between particular societies and, consequently, a relativization of these particular cultures, including religion. Today people become increasingly aware of the fact that a particular religion is but one among numerous alternative creeds. In Western individualistic culture this may lead to a 'wild eclecticism' of the kind we usually can observe in spirituality and New Age. This eclecticism, in turn, may lead to tolerance towards other religious interpretations.

The second characteristic is called from dogma to experience. A consequence of globalization is the crystal clear insight that not all religions can be true. As Liselotte Frisk points out, you cannot simultaneously believe in heaven or hell after death and believe in reincarnation. People then conclude that all belief systems are relative; the claim of absolute dogma is undermined.

The next distinctive feature is from collective to personal. When belief in religious dogma is weakened, when institutionalized religion loses its importance, it may lead to the empowerment of the individual. Referring to the work of Peter Beyer, Frisk states that globalization favours privatization. In this context we could mention that Heelas (2008: $32 \mathrm{ff}$.) points at several keywords related to what he calls New Age spiritualities of life-activities or practices; healing, well-being, love, humanistic values, and 'affective, expressive relationality. These keywords are all related to the personal life.

Then there is a notable shift from a hierarchical to an egalitarian life-view. This feature collides with the view of Herrick, who stated that the new spirituality dispenses with the 'egalitarian spiritual community'. But it harmonizes with conclusions drawn by Woodhead and Forman, who maintain that egalitarianism is taken for granted by the new spirituality (Woodhead), or that the panentheistic view of God, expressed by interviewees, is compatible with 'our democratic and egalitarian mindset' (Forman). Globalization promotes two opposed responses, Peter Beyer asserts. It either leads to a conservative response and a polarization of 'we versus them', or to a liberal response, which in the field of religion leads to ecumenicalism and tolerance, to inclusion instead of exclusion. And these concepts go well with egalitarianism and democratic values.

Another shift is from a theological to an anthropological dimension. Subjective experience and egalitarianism may lead to a change away from theology. Instead, there is an emphasis on individual growth, on the sacralisation of the self (Heelas). 
The final shift, as mentioned by Liselotte Frisk, is a shift in focus from life after death to this-worldliness. Representatives of contemporary spirituality are more interested in this world than in the world to come. One of the consequences is that God is conceived as immanent in man and in the world, rather than transcendent. Ideas of eternal punishment, hell, and damnation are excluded from the new spirituality. This shift is, of course, also noticeable in contemporary interpretations of, for example, Christianity.

Now, what common denominators can be found among the scholars presented above? One of them, I think, is related to a different perception of divine immanence, including man, mentioned especially by Forman. Herrick does not expressly mention that concept, but he talks about nature being infused with life force, which is close to, if not equivalent with the idea of immanence. A second, related issue pertains to the human capacity to realize this divine dimension through a process of spiritual growth. This is probably the 'hidden spiritual knowledge' that Herrick hinted at, or the sacralisation of the self, as mentioned by Heelas and others. Keywords such as healing, wellbeing, and practice fit into this aspect, in other words the experiential basis of spirituality. A third commonality is the altered view of sacred scripture as being largely symbolical or allegorical, a view opposed to fundamentalism. Other characteristics comprise egalitarianism and eclecticism, pluralism and tolerance.

It is my conviction that the fundamental traits of the new spiritualities of life are in harmony with the great mystical and spiritual traditions within world religion. Space does not allow me to go all too deep into this issue. But let me just hint at some dimensions in the phenomenology of mysticism that harmonize with spirituality. In other words, we now move from the new spirituality to the old spiritualities.

\section{The old spirituality}

Contemporary spirituality shares a panentheistic view of God with a substantial part of traditional mysticism. Such a view is usually associated with the language of emanation. The divine world overflows, the end product of which is creation. But this also means that part of the divine remains in the product. The whole of creation will eventually return to its origin. This is the dominating, basic scheme in mystical theology, greatly influenced by Neoplatonism.

But while the God of spirituality appears to be diffuse, the virtuosi of mysticism have more to say about a God who is both hidden and revealed. 
The mysteries of God's Word, says Pseudo-Dionysius in the early sixth century, 'lie simple, absolute and unchangeable in the brilliant darkness of a hidden silence' (Dionysios Areopagita 1987: 997A-b, p. 135). Influenced by Neoplatonic thought, Dionysius taught that this hidden God nevertheless can reveal himself to the earnest seeker. The method is 'absolute abandonment of yourself and everything' (ibid.). About six hundred years later, the Cistercian Friar Bernhard of Clairvaux adds a new dimension. The hidden God reveals himself through love and the practice of virtues: chastity, patience, cheerfulness, simplicity, and humility. Such a soul, writes Bernhard in his grandiose commentary to the Song of Songs, 'is worthy of the caresses of the Bridegroom' (Bernhard of Clairvaux 1980: Sermon 69:1; cf. Halflants 1971: xvii).

About one hundred years later we encounter a similar message in the mystical theology of Bonaventura, one of the great mystical theologians among the Franciscans. Perhaps he can be described as an eclectic of his time, combining ideas from St Augustine, Pseudo-Dionysius, Gregory the Great, the Cistercian masters, and others. The three pillars in his theology are the concepts emanation (emanatio), exemplarity (exemplaritas), and consummation (consummatio), three dynamic terms that describe how the divine 'fountainfullness' emanate into the Word and the Spirit. The 'fountain-fullness', or Father, cannot be described in words. We can only approach him through the second person of the Trinity. Through him the whole of creation can return to its divine origin (McGinn 1998: $88 \mathrm{ff}$.).

This basic structure can be found again in the work of the famous Dominican Meister Eckhart, writing somewhat later than his Franciscan brother.

In his Latin works Eckhart described this process of emanation with the terms exitus and reditus; in his German sermons he uses the words $\hat{u} z v l i e z e n$ and durchbrechen (McGinn 1981: 30 f.). This whole process has its counterpart in the human being, since in the ground of the human personality there is a 'little spark', the essence of which is identical with the godhead, described in apophatic terms.

But the distinction between God concealed and revealed is not limited to the male representatives of Christian spirituality. The Benedictine Nun Gertrud of Helfta had numerous visions of the divine world. She does not hesitate, however, to describe the godhead in impersonal terms, with the language of infinity:

Let me be submerged in the abyss of the sea of your most merciful goodness. Let me perish in the deluge of your living love, as a drop of the sea dies in the depth of its fullness. Let me die, let me die, in the outpouring of your 
immense mercy, as dies the spark of flame in the irresistible force of the flood. (Gertrud of Helfta: Documenta spiritualum exercitionum 4, quoted in McGinn 1998: 274.)

Gertrud also frequently uses the language of love and undisguised eroticism in order to express her intimate relationship with the divine world. The bridegroom, she writes, prefers to be alone with his bride, in the nuptial chamber, where they can 'delight one another with the charm of intimate converse and tender embraces' (Marnau 1993: 32 f.).

Another example is Mechthild of Magdeburg, one of the most renowned beguines from the thirteenth century. The title of her book, The Flowing Light of the Godhead, reveals an emanational view of God and creation. God is primarily described as light, a light which encompassed the blessed soul, if it only knew. Just like her Benedictine sister, Mechthild describes the soul's return to this light in erotic imagery.

Then a blessed stillness

That both desire comes over them.

He gives himself to her,

And she gives herself to him.

What happens to her then-she knows-

And that is fine with me. (Quoted in McGinn 1998: 237 f.)

There is no doubt that the mystical theologies referred to have an experiential base. The mystics mentioned know from their own overwhelming experience that the divine is immanent in creation. Their texts are merely reflections on their own experiences. But while representatives of the new spirituality have a feeling of divine presence, the classical mystics know from their own experience. There is a difference in degree, not in kind.

If we move to the fascinating world of Jewish mysticism, the world of Kabbalah, we do find similar ideas about the hidden and revealed God, immanent in creation and in man. One of the most important Kabbalistic writings is Sefer ha-Zohar, 'The Book of Splendour'. In this lengthy and complex text one encounters a number of mystical techniques which all aim at 'cleaving' (devequt) to God. Which God? Zohar distinguishes between a hidden God and its revealed characteristics. The former is known as ein sof, 'without end', while the latter is described as the ten sefirot, the emanations of the hidden god, arranged in three triads. To this is added the tenth and final emanation- 
Malkhut, 'Kingdom', or Shekhinah, which means 'divine presence', inherent in creation and therefore accessible to the searching of the mystic.

How is one to experience this divine presence? Zohar proposes various ways. The most important way is by prayer and by study of the Torah, especially at midnight. The intention is to 'draw down' divine energy to the world. Another technique is that of rotating the closed eye, which leads to the experience of numerous colours, symbols of the middle triad of the sefirot system. Yet another technique described in the Zohar is staring at a dish of water that has been placed in the sunlight. The play of light and shadows that is created is interpreted as visual traces of the sefirotic system.

A similar, although more developed, scheme can be found in Lurianic Kabbalah in the sixteenth century. Limitations of space do not allow us to go deeper into this fascinating world of experientially based thought. Instead, I will present a few examples of a panentheistic God in Islamic mysticism or Sufism. In its early period there are clear signs of the immanent bent. Didn't the Holy Koran mention that God is closer than his jugular vein (Süra 50:16)? And isn't it true that 'withersoever ye turn there is the Face of God' (Süra 2:109)? After all, God has 'put signs into nature and into the human soul' (Süra 51:21). ${ }^{4}$ It is therefore not surprising to find the following beautiful lines attributed to an eighth century Egyptian Sufi:

O God, I never hearken to the voices of the beasts or the rustle of the trees, the splashing of waters or the song of birds, the whistling of the wind or the rumble of thunder, but I sense in them a testimony to Thy Unity (wahdānìya), and a proof of Thy Incomparableness; that Thou art the Allprevailing, the All-knowing, the All-wise /-/. (Abu Nuaym al-Isfahani: Hilyat ul-Awliya (The Ornament of the Saints) 9:342, quoted in Arberry 1972: 52 f. See also Schimmel 1975: 46.)

At the same time, in another part of the Muslim empire, another influential Sufi called Tirmidhi wrote about the hidden and revealed God, a theme so common in Islamic mysticism. Tirmidhì makes a distinction between God's essence and God's attributes. Although God's essence cannot be described, Tirmidhì nevertheless uses terms such as existence, the inner (bäțin), and the hidden, in order to say something, hinting at the indescribable. But his attributes can be described and perceived, attributes such as radiance, mercy, and 
wisdom. They are realms of light, hierarchically ordered. Creation originates from this divine light (Radtke 1980: 59 ff.).

Man has a unique place in this creation. Equipped with a lower and higher soul, man oscillates between the angel and the beast. With her higher soul, man can reach beyond the angels, to direct knowledge of the light of God (ma'rifa) (Radtke 1980: 62 ff.; see also Radtke \& O’Kane 1996: 44 ff.).

In the eleventh century the need arose to summarize the teachings of the Sufis. Different summaries or handbooks were published, one of them being the 'Unveiling of the Hidden' of Hujwiri. We might ask: what veil? The answer to that is, of course, the veil that separates us from the hidden or immanent God.

We cannot leave Sufism without mentioning the greatest master (alShaykh al-akbar) Ibn 'Arabi (d. 1240). His view of God is a cornerstone in his numerous writings, influencing the Muslim world from then until now. According to Ibn 'Arabi there is only one Reality, that is God, which can be discussed from two angles. God is Haqq, the Real, regarded as the Essence of the phenomenal world, impossible to describe with words; and God is Khalq if we regard him as the manifestation or the self-disclosure of that Essence. There is fundamental unity, but empirical multiplicity. The relation between the One and the many is like the body and its limbs, or as the mirror and its reflected images (Affifi 1979: 10 f.; cf. Landau 1959: 31 ff.). Haqq means transcendence, while Khalq represents immanence.

If you assert (pure) transcendence you limit God, And if you assert (pure) immanence you define Him.

But if you assert both things, you follow the right course,

And you are a leader and a master in gnosis. (From Fusūs al-hikam, quoted in Affifi 1979: 21.)

God's attributes can be understood in his 99 beautiful names, for example Life, Knowledge, Power, Speech, and Justice. These attributes are mirrored in the universe. God's Power, for example, is passively reflected in all he has created. Actively it is inherent in different types of activity, from the buzzing of bees to the outbursts of volcanoes (Chittick 1989: 6-12). If we ask ourselves where I can find God, the answer is: wherever he is present, through his essence, and his attributes. If we ask ourselves how I can find God, the answer is: by unveiling the veils of existence. 
Union with God has been expressed in so many ways. There is great variety in the language of the Sufis. Let me finish this very short presentation with a few lines from the famous Jalāl al-dīn Rūmì (d. 1273):

I have put duality away, I have seen that the two worlds are one;

One I seek, One I know, One I see, One I call.

I am intoxicated with Love's cup, the two worlds

have passed out of my ken;

I have no business save carouse and revelry. (From Diwan-i Shams-i Tabriz, quoted in Nicholson 1966: 96.)

\section{The new and the old: glocal spirituality}

In addition to classical panentheistic descriptions of God we could go into presentations of the view of man, and man's return to his or her origin. There is no room for that in a short article. So let us now return to the new spirituality, especially as defined by Forman and his colleagues. It is obvious that the defining characteristics of grassroots spirituality can be recognized in classical mysticism.

There are other commonalities between spirituality and mysticism. There is a shared scepticism towards the written word, expressed for example in negative theology. Words, texts, or religious dogma are like the finger pointing to the moon-in an expression borrowed from Zen Buddhism.

If the word religion is derived from the Latin ligare, it means to 'bind' or to 'connect'. If it is derived from re-ligare, it means 'to reconnect'. Whether the former or the latter, we do not find many serious attempts to connect or reconnect in the world of institutionalized religion, at least as far as connecting to our fellow human beings is concerned. We mostly observe the opposite: division, schism, conflict, and even violence in the name of God.

It is my firm belief that the conditions for mutual understanding are much better in the world of spirituality, grounded in practice and personal experience. In the world of spirituality it is a commonplace that man is more than the sum total of words and thoughts. Convinced that religious dogma cannot grasp all of reality, representatives of spirituality usually exhibit an attitude of openness and tolerance towards other religions. When I visited the HalvetiJerrahi order of dervishes in Istanbul, Turkey, and asked the spiritual leader if I could participate in their ritual, the answer was spontaneous: 'Of course you can participate. The only thing that matters is the one God.' 
The attitude I met among Sufis in Turkey reminded me of Robert Jay Lifton, an American psychiatrist and a prolific writer. In one of his more optimistic books he writes about what he calls the Protean self (see Lifton 1992). This is a word derived from the Greek sea god Proteus, a god of many forms, a god who could adapt to different situations, a shape shifter. The Protean self is a many sided self, a person with free-floating emotions, and a person with an uneasy relationship to the holding of ideas. 'Idea systems can be embraced, modified, let go, and re-embraced', in other words, the Protean self is the very opposite of the fundamentalist self. The flexibility and adaptability of the Protean self gives us hope, Lifton says, and I certainly do agree.

Proteanism involves choice, Lifton continues. According to him, certain forms of Proteanism 'are not only desirable but necessary for the human future'. Many of us do have a tendency towards Protean openness. But absolute Proteanism is neither possible nor desirable. What we do need is a certain measure of Proteanism and an anchorage in a belief system or a system of moral values. This is the antidote to fundamentalism and apocalyptic violence. This is, precisely, what is meant by glocal spirituality.

Finally, when Lifton mentions that the Protean self seeks to be both fluid and grounded', it reminds me of some favourite metaphors being used in an ancient Chinese book of wisdom called the Tao Te Ching. The author Lao Tzu uses imagery from daily life in order to illustrate man's proper attitude in a time of crisis, a period in Chinese history labelled as 'the time of a hundred wars'. Try to be like water! Lao Tzu exhorts. Water always manages to pass obstacles. Just imagine sea waves rolling to the coast, passing by a big stone. Water always searches the lowest point, and in that it is closest to Tao, the Absolute. In manifestation water can be as serene as a lily pond or as wild as the stormy sea, and in form vaporous as steam or as solid as ice. Let us read a few lines from the Tao Te Ching (verse 8, translation by Ellen M. Chen, 1989):

A person with superior goodness is like water,

Water is good in benefiting all beings,

Without contending with any.

Situated in places shunned by many others,

Thereby it is near Tao.

Or consider this quote (verse 76 ):

At birth a person is soft and yielding,

At death hard and unyielding. 
All beings, grass and trees, when alive, are soft and bending, When dead they are dry and brittle.

Therefore the hard and unyielding are companions of death, The soft and yielding are companions of life.

Try to visualize a small bush, with its roots firmly in the soil. But its branches and leaves are flexible. Thanks to its firmness and flexibility, the bush can stand the strong wind by yielding. In yielding is strength.

People with a Protean personality are aware of their cultural identity, and with a high sense of empathy they encounter the other with a sense of curiosity and wonder. God is, ultimately, a mystery. So is life. Let us search for commonalities, without shutting our eyes to the differences. Let us regard sacred scriptures in general as different cultural attempts to cope with our fundamental existential questions. In spirituality there is a good ground for such commonalities.

In my perhaps utopian world, I have visualized a meeting of high-level politicians, trying to solve one of those seemingly never-ending conflicts. They all arrived a day earlier in order to have time to associate as human beings. They all brought their family albums, with pictures of their children and grandchildren. Then they cooked dinner together. In the evening they discussed Rūmī and Eckhart, by the open fire. Like the two Maasai men mentioned in the beginning, the politicians exclaimed: 'Yes indeed, we do have so many things in common.' The day after the meeting took place. Afterwards the world was taken by surprise. Never before did politicians reach mutual understanding in such a short time. Documents were signed, with a smile on their faces. Pictures were taken, hands were shaken.

Peace at last.

Peace in the name of God.

Peace in the name of humanity.

\section{References}

Affifi, A. E.

1979 The Mystical Philosophy of Muhyid din-ibnul Arabi. Lahore: Sh. Muhammad Ashraf. (First published in 1939)

Arberry, Arthur J.

1972 Sufism. An Account of the Mystics of Islam. London: George Allen \& Unwin. (First published in 1950) 


\section{Bernhard of Clairvaux}

1980 On the Song of Songs IV. Transl. by Irene M. Edmonds. Kalamazoo: Cistercian Publications.

\section{Chittick, William C.}

1989 The Sufi Path of Knowledge. New York: State University of New York Press. Dionysios Areopagita

1987 The Mystical Theology. Translated by C. Luibheid. New York: Paulist Press.

Halflants, M. Corneille

1971 Introduction to Bernhard of Clairvaux, On the Song of Songs I; pp. ix-xxx. Trans. by Kilian Walsh. Kalamazoo: Cistercian Publications.

\section{Forman, Robert K. C.}

1990 (ed.) The Problem of Pure Consciousness. Mysticism and Philosophy. New York: Oxford University Press.

1998 The Innate Capacity. Mysticism, Psychology, and Philosophy. New York: Oxford University Press.

2004 Grassroots Spirituality. Exeter: Imprint Academic.

Frisk, Liselotte

2009 Globalization: An Important Key Factor in Contemporary Religious Change. To be published in the Journal of Alternative Spiritualities and New Age Studies.

\section{Heelas, Paul}

2008 Spiritualities of Life. New Age Romanticism and Consumptive Capitalism. Oxford: Blackwell Publishing.

\section{Heelas, Paul \& Linda Woodhead}

2005 The Spiritual Revolution. Why Religion is Giving Way to Spirituality. Oxford: Blackwell.

Herrick, James A.

2003 The Making of the New Spirituality. The Eclipse of the Western Religious Tradition. Downers Grove: InterVarsity Press.

\section{Kimball, Charles}

2002 When Religion Becomes Evil. New York: HarperSanFrancisco.

\section{Landau, $\mathbf{R}$.}

1959 The Philosophy of Ibn 'Arabi. London.

\section{Lifton, Robert Jay}

1992 The Protean Self. Human Relisilence in the Age of Fragmentation. Chicago \& London: The University of Chicago Press.

\section{Marnau, $M$.}

1993 Introduction to Gertrud av Helfta, The Herald of Divine Love; pp. 5-44. Transl. and ed. by M. Winkworth. New York: Paulist Press.

\section{McGinn, Bernard}

1981 Theological Summary. In: Meister Eckhart, The Essential Sermons, Commentaries, Treatises, and Defense; pp. 24-61. Translation and Introduction by Edmund Colledge and Bernard McGinn. New York: Paulist Press.

1998 The Flowering of Mysticism. New York: Crossroad. 


\section{Antoon GeELS}

Nicholson, R. E.

1966 The Mystics of Islam. London: Routledge and Kegan Paul. (First published in 1914)

Radtke, $B$.

1980 Al-Hakim at-Tirmidhi. Ein islamischer Theosoph des 3./9. Jahrhunderts. Freiburg: Klaus Schwarz Verlag.

Radtke, B. \& J. O'Kane

1996 The Concept of Sainthood in Early Islamic Mysticism. Two works by Al-Hakim Al-Tirmidhi. An annotated translation with introduction. Richmond: Curzon Press.

\section{Schimmel, A.}

1975 Mystical Dimensions of Islam. Chapel Hill: University of North Carolina Press.

\section{Tao Te Ching}

1989 A New Translation with Commentary by Ellen M. Chen. New York: Paragon House.

\section{Ward, Keith}

2004 The Case for Religion. Oxford: Oneworld. 